\title{
心因加重性が疑われた若年者腰痛の症例
}

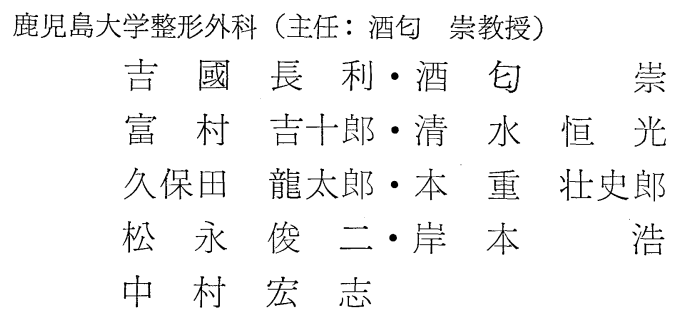

\section{Psychosomatic Low Back pain in the Young}

by

N. Yoshikuni, T. Sakou, K. Tomimura, T. Shimizu, R. Kubota, S. Motoshige, S. Matsunaga, H. Kishimoto and H. Nakamura

Department of Orthopaedic Surgery Faculty of Medicine, Kagoshima University. Kagoshima. (Director: Prof. Takashi Sakou, M. D.)

It is important to differentiate emotional responses from the organic disorders in treating the patients of low back pain. Especially in indicating surgery, little attention has been paid to psychogenic low back pain in the children. We report four young patients who showed remarkable manifestations of sciatica. We revealed that emotional factors or psychogenic manifestations of symptoms with lumbar disc herniation were involved in these patients after surgery or careful observations and examinations.

\section{はじめに}

若年者の腰痛は種々の原因が考えられるが, その頻 度は成人に比し少なく, しかも心因性要因の介入が原 因と考えられる腰痛は，きわめて稀であり，てれらの 症例についての報告はあまり見当らない様である.我 々はこの様な 4 症例を経験し, その内 2 症例に手術を 行ったが，乙れらの症例について検討及び反省を加え 報告する。

\section{症例}

症例は 16 才女子 3 例之 17 才男子 1 例である（表 1). 症例を供覧する.

症例 1. 17 才男子

主訴: 腰痛, 歩行障害

既往歴：昭和 54 年 4 月虫垂切除術を受けた.

現病歴：昭和 53 年 10 月, 運動会にて腰痛が出現し
表 1 症例

\begin{tabular}{|c|c|c|c|c|}
\hline 症例 & 年齢 & 性別 & 既 往 歴 & 治 療 \\
\hline 1 & 17 歳 & 男 & $\begin{array}{l}\text { 虫垂切除術, 過敏性 } \\
\text { 大腸炎, 膵臟炎 }\end{array}$ & 保存的 \\
\hline 2 & 16歳 & 女 & 虫垂 切除 術 & Love法 \\
\hline 3 & 16歳 & 女 & 胆孁炎, 虫垂切除術 & Love法 \\
\hline 4 & 16歳 & 女 & $\begin{array}{l}\text { 虫垂切除術, 扁桃腺 } \\
\text { 摘出術, 腎炎 }\end{array}$ & 保存的 \\
\hline
\end{tabular}

たが放置していた．昭和 55 年 4 月，高校入学後に腰 痛が增強し, 同時に頭痛, 腹痛が出現し, 某医にて過 敏性大腸炎の診断を受け, 以後休学した. 昭和 56 年 1 月, 腰痛が増強し, 某整形外科にて保存的治療を受 けたが，症状の軽快はみないままに，昭和 56 年 4 月， 復学したが腰痛は更に増強し, 歩行困難となった為, 同年 12 月, 当科へ入院した. 
入院時所見：脊柱の可動制限は著明で, 脊柱に印打 痛, 圧痛があり, 傍脊柱筋の緊強は強く圧痛を認め た．ラセグ徴候は両側 $30^{\circ}$ で陽性, 膝蓋腱反射, アキ レス腱反射は両側とも軽度光進していたが，バビンス キ一反射は陰性で, 膀胱直腸障害も認められなかっ た. 知覚障害は第 12 胸髄節以下の知覚鈍麻を認めた が，日時により著明に変動した（図 1)。ミエログラ ムでは $L_{5}$ 神経根に Perineural cyst が認められる 以外，特飞異常所見は認められなかった（図 2 ）.

入院後経過：図 1 亿示した如く, 知覚障害のレベル

拉湖 1 .

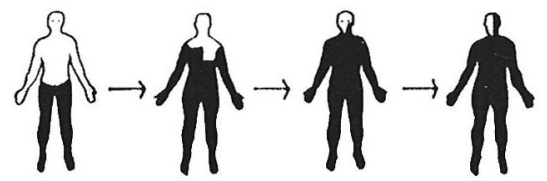

[II 2 . 2 .

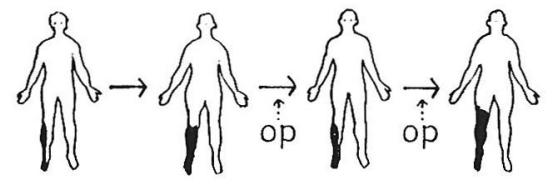

拉湖 3 .

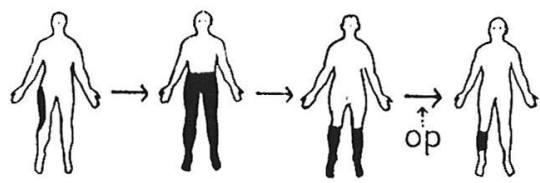

姃咕 4 .

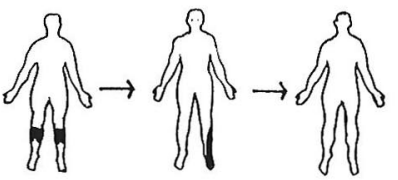

図 1 知鸴障害の推移（症例1.17才, 男子)
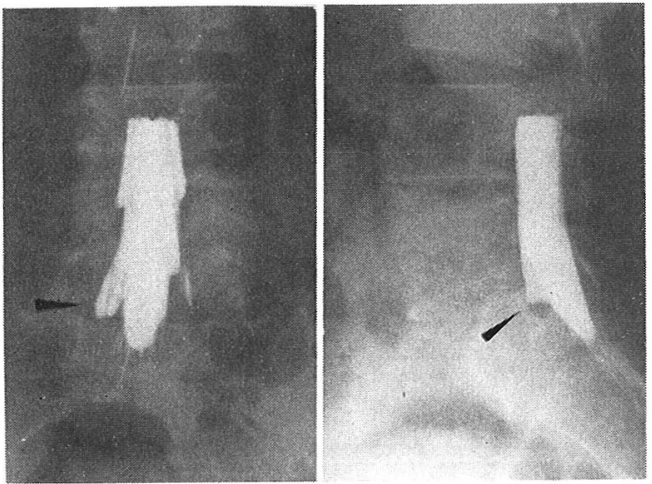

図2 症例 $1 の$ myerogram perineural cyst を認める。
は日時により著明に変動し，歩行障害は医師の見てい る場合と，そこでない場合とでは，その程度にかなり の差を認めた，その内に四肢痙樂発作が出現する様に なった為，心療内科を受診した。 心理テストでは CMI は第 1 領域にあったが，心療内科医との consultation に扣いて 虚言と自己防衛的態度が強々, 臨床面 に扔いて神経症尺度が高いと判断され，心療内科佂云 科の上，心身医学的治療を行った。 その結果，腰痛， 歩行障害は消失し，現在は健康な高校生活を送ってい る.

症例 2.16才女子

主挀：腰痛

既往歴：昭和 55 年 10 月虫垂切除術を受けた.

現病歴：昭和 56 年 9 月, 誘因なく腰痛が出現し, 同年 11 月 14 日，某整形外科受搒し，根性坐骨神経痛 の診断で保存的治療を行うむ，症状は軽快せず，同年 11 月 20 日, 起床時に腰部激痛が出現して 起床不能と なり，某整形外科へ入院した．持続硬膜外ブロック等 の保存的治療を受けるも，腰痛は軽快せず，昭和 57 年1月19日，当科へ入院した。

入院時所見：脊柱は可動制限が著明で, 叮打痛, 圧 痛を認め，傍脊柱筋に压痛があった。 ラセーグ徴候は 右 $60^{\circ}$, 左 $80^{\circ}$ で陽性で, 膝蓋腱反射, アキレス腱反 射は正常で，バビンスキー反射は陰性であった．知覚 障害は右下腿外側より足部に知覚鈍麻を認め, 図 1 の 如く日時により変動した.

ミエログラム所見： $\mathrm{L}_{5}$ 神経根, $\mathrm{S}_{1}$ 根経根の根囊像 の陰影欠損を認めた。

デスコグラム所見：椎間板像は正常と思われたが， $\mathrm{L}_{4} / \mathrm{L}_{5}, \mathrm{~L}_{5} / \mathrm{S}_{1}$ 間に造影剂注入時に腰部から右下肢への 著明な反応性疼痛が出現した。疼痛は $\mathrm{L}_{5} / \mathrm{S}_{1}$ 間への注 入特に特に著明であった。

昭和 57 年 2 月 23 日, Love 法 ( $\mathrm{L}_{5} / \mathrm{S}_{1}$ 間) を施行 した. 術中, 右側 $S_{1}$ 神経根が軽度膨隆した椎間板に 圧排されている所見を認めた。 術後, 症状は一時的に 軽快したが， 3 週目頃より再び゙同様の症状を訴えた 為, 部位喨断目的にて $\mathrm{L}_{5}$ 神経根ブロックを行なっ た. その結果, ラセーグ徵候は殁よ゙消失し, 腰痛も 著明に軽快減したため, 同年 6 月 3 日, $\mathrm{L}_{4} / \mathrm{L}_{5}$ 間の Love 法を施行した. しかし, 症状の軽快は得られな かった，心因性要因の介入屯考えられた為，録療内科 を受部, CMI は第 1 領域にあったがパラノイアの尺 度が高く, ヒステリー反応もみられた為, 心身医学的 
治療を行なった，その結果，ラセーグ徵候は右 $60^{\circ}$ 陽 性, 左陰性となり, 腰椎の運動制限屯著明に軽減, 歩 行, 運動にあ困難を感じなくなった.

症例 3,4 とむに 16 才女子であるが, 上記 2 症例 之同様江腰痛, 下肢痛, 知覚障害を強く訴えた症例で あり, 症例 3 は, ラセーグ徵候は右 $70^{\circ}$ 陽性, 左 $80^{\circ}$ 陽性で, ミエログラムにて椎間板ヘルニアの所見があ り, Love 法を行なったが軽快しなかった. 症例 4 は ラゼーグ徵候は陰性であり，、エログラムであ特に異 常は認めなかった. 2 症例とも心身医学的治療により 初めて症状の著しい軽快を得た。

\section{総括 及び結び}

成人の腰痛に心因の介入例の多い事は指摘されてい るが，若年者関しての報告は見当たらない様であ り, 関心が殆ど払われていないと考えられる. この理 由としては, 若年者の腰痛は成人に比し頻度的に少な く，小児では金銭的帰望亡は無関係な事などが挙げら れる. しかし, 近年社会の複雑化に伴い, 進学の問 題, 友達関係のトラブル等により心因介入例少なから ず存在するむのと考えられる.

著者らがこてに報告した 4 症例は根性坐骨神経痛と 極めて類似した症状を呈し, 綿密な観察により, 或い は椎間板ヘルニア摘出術の手術後症状の改善が無く再 検討の結果，心因の介入が明らかとなった症例であ る. 手術した 2 症例は, ラセグ徴候著明で, ミエログ ラムにても根營像の欠損があり, デスコグラムにて 1 例は疼痛の再現が見られているので，心因の overay した可能性もある. 4 症例と屯保存的治療や観血 的治療に全く反応せず, 愁訴が多彩であり, 知覚障害 のレベルが日時により著明に変動したという特徵をあ っていた. また 4 症例とも表 1 亿示すように腹部疾患 の既往を有しており，てれら腹痛を主訴とする疾患と
心身症との関連性が疑われた. 心因の関与を見い出す 事は特に手術を行う場合に重要であり, 詳細な現病歴 の聴取, 臨床所見, 経過, 患者の置かれた背景等に充 分な注意が払われるべきである. 心理テストは 1 例の みが CMI 第 3 領域で, 他の 3 例は正常領域にあり, 補助診断には余り役に立たず，心因介入の疑いがあれ ば精神科や心療内科㑑談することが肝要である.

（心身医学的立場より種々のご助言をいただいた鹿児 島大学医学部鑑一内科野添新一講師に深謝いたしま す)

\section{文献}

1）林浩一郎：整形外科飞必要な心理テスト。整形 外科, 25: 689-693, 1974.

2）苤木初枝, 柴㥓唇一, 大谷 清: 腰痛としての 心身症. 整形・災害外科, $24: 1477-1481,1981$.

3) 丸田俊彦: 慢性疼痛々精神医学. 心身医学, 21: 393-398, 1981.

4）遠山尚孝：心身症に求ける治療抵抗（III），精 身医. 12: 322- , 1972.

5) 山口義臣, 山本希雄: 腰痛症の疫学, 整形外科 Mook, 11: 9-19, 1979.

\section{質 問}

4 症例之屯虫垂炎などの消化器症状が多いようです けれど，乙れらと心因性の介入之何か関係があるので しょうか。

\section{解 答}

既往歴に, 消化器疾患が多いというのは, irritable colon cyndrone といわれるように，乙れらの患者 は, 過去に何んらかの腹部症状を訴えているのが多い ような因象を受けた。 